\title{
新幹線沿線住民の振動被害感を構成する要因に関する研究 A STUDY ON FACTORS CONSTITUTING ANNOYANCE DUE TO SHINKANSEN RAILWAY VIBRATION
}

\author{
横島潤 紀*, 田村明弘** \\ Shigenori YOKOSHIMA and Akihiro TAMURA
}

\begin{abstract}
This study was focused on community response to Shinkansen railway vibration. Social surveys for housewives in detached houses were carried out along the Tokaido Shinkansen Line in Kanagawa Prefecture. Applying path analysis to the response, we have clarified Shinkansen railway vibration annoyance. The results were as follows: 1)Most of inhabitants within 100 meters from the railway were annoyed by the vibration. 2)Annoyance was directly affected by the irritation, auditory plus visual effects due to the vibration and evaluation to the change of the vibration environment and indirectly influenced by vibration exposure. 3)Noise was also one of factors constituting vibration annoyance.
\end{abstract}

Keywords : Tokaido Shinkansen, Ground Vibration, Noise, Social Survey, Path Analysis 東海道新幹線，地盤振動，騒音，社会調査，パス解析

1.はじめに

東海道新幹線鉄道は昭和 39 年に日本最初の高速鉄道として開通 以来，鉄道輸送力を大幅に增大させてきたが，その反面沿線住民に 対して騒音及び振動の環境問題を引き起こしてきた。新幹線振動に 関する基準としては，昭和 51 年 3 月に環境庁長官から運輸大臣に対 して「環境保全上緊急を要する新幹線鉄道振動対策について」の勧 告が出されおり，この中で測定方法とともに基淮となる指針值（振 動レベルで 70dB）が示されている。この指針值が作成された当時と 現在の状況を比較すると，防振技術の発達により車耐本体から発生

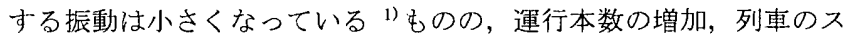
ピードアップ等によって新幹線沿線における振動環境が改善されて いるとはいえない。特に平成 4 年から営業運転を開始した 300 系車 両「のぞみ」は，車体軽量化等による振動低減対策を行っているが， 最高速度 $(270 \mathrm{~km} / \mathrm{h})$ に近い速度で走行する場合に発生する振動が従 来の 0 系及び 100 系車雨より大きくなると報告されている ${ }^{2) 。 ~}$

近年の新幹線振動に倸る苦情の多くは指針值以下の所で発生して おり，沿線地域における住居地区開発の拡大，良好な居住環境を望 む住民の增大等を考えあわせると，振動問題の顕在化が㲘念される。 感覚公害である振動問題の解決を図る上では，振動対策は住民の被 害感を低減することを目標として行われるべきである。その意味で
は，振動による被害感の意識構造を解明することは，住民の要望を 反映した振動対策の目標をより明確にするとともに，それぞれの目 標に応じた対策手法の開発を促進させることになる。

新幹線鉄道騒音に関する住民意識を扱った砶究では，曽根等 ${ }^{3)}$, 田村 ${ }^{4)}$, 町田 ${ }^{5)}$, 川端 6,7)による報告が見られる。一方, 新幹線振 動を扱った研究では，村松等 ${ }^{8}$ は振動の曝露量と様々な愁訴数との 関倸を明らかにしたが，調查が勧告以前に行われていたため，結果 をそのまま対応させることは難しい。住友等 ${ }^{99}$ はアンケート調查か ら新幹線振動に対する住民の意識，意見や要望を明らかにしたが， 住民の意識構造については言及していない。近年では道路交通振動 や水平方向の振動感覚に関する研究 ${ }^{10,11}$ 擞多く発表されているが, 新幹線振動に着目した調查研究は行われておらず，「のぞみ」運行後 の振動環境を住民がどのように評価しているかは明らかではない。 本研究では，平成 7 年及び 8 年に神奈川県内の東海道新幹線鉄道 沿線の住民を対象としたアンケート調査から得られた結果を基に， 新幹線振動に対する住民の意識を把握するとともに，新幹線振動に よる被害感を構成する要因について検討を加える。構成要因の解明 では住民の被害感をモデル化し，パス解析の手法を用いて各要因の 影響度及び影響過程を明らかにすることを目的とする。なお，本論 文は口頭発表 ${ }^{12 \sim 14)}$ の内容を再構成したものである。
* 神奈川県環境科学センター

** 横浜国立大学工学部建設学科建築学教室 教授・工博
Kanagawa Environmental Research Center

Prof., Dept. of Architecture, Faculty of Engineering, Yokohama National University, Dr. Eng. 


\section{2. 調查概要}

\section{1 調査場所}

調査場所は神奈川県内の東海道新幹線沿線の住宅密集地区で，新 幹線以外の振動源（道路，工場等）が存在しない所とした。新幹線 軌道からの距離により調査場所を分類し， $100 \mathrm{~m}$ 以内の沿線地区, $100 \mathrm{~m}$ 以遠の遠隔地区（100～200 m) と対照地区（200 m〜500 m) の 3 地区とした。遠隔地区と対照地区は沿線地区の近辺に位㯰して いる。平成 7 年には沿線地区 (9 地区), 平成 8 年には沿線地区 ( 5 地区)，遠隔地区（4 地区）及び対照地区（3 地区）で調査を行った。 沿線地区の概要を表 1 に示寸とともに，沿線地区と遠隔地区の 1 例 を図 1 に示寸。沿線地区の調查場所 $E$ と $G$ については，平成 7 年と 8 年の両年で調査を行ったので，沿線地区の調査数は 12 地区である。 また，遠隔地区と対照地区の調查場所は，それぞれ沿線地区の調査 場所 $\mathrm{E}, \mathrm{F}, \mathrm{G}, \mathrm{L}$ と F, G, L の近くである。

\section{2 アンケート調査}

アンケート調査の対象家屋は調査地区内の全ての戸建て住宅とし た。回答者を主婦としたが，都合の悪い場合には家族の他の方でも 可とした。対象を主婦としたのは在宅時間が長いために，振動に対 する反応がある程度確立されていると考えられたからである。調查 は対象家屋に㪼問票を配布し，郵送にて回収する方法とした。調相 の実施状況を表 2 に示す。有効回収数は沿線地区で 584 ，遠隔地区 で117，対照地区で 161 であった。

平成 8 年のアンケート調査で用いた翼問票の構成を表 3 に示す。 振動に関する質問は，翼問票上で示した 7 種類の振動源の中から 「感じる振動」「「気になる振動」に該当するものを全て回答し，さ らに「気になる振動」については「最も気になる振動，次に気にな る振動」(以下，「気になる 2 振動」という。）も回答する方法とした。 「気になる 2 振動」として指摘されたそれぞれの振動については, 「振動による影響」，「振動環境の変化に対する評価」，「振動に対す る我慢の度合い」を聞いている。ここで「振動環境の変化に対する 評価」は，「のぞみ」の運行にともなら振動環境の変化を把握するた めに設けた項目である。騷音に関する質問項目は，提示した音源が 9 種類であること以外は振動と同様な構成である。なお，平成 7 年 の啠問票も基本的には平成 8 年と同じ構成であったが，回答の評価 段階数が一部異なっていた。例えば「振動による影響」は 5 段階（1. 『頻繁にある』〜 5. 『全くない』)，「振動環境の変化に対する評価」 も5段階（1.『良くなった』〜 5.『悪くなった』）であったが，回答 の記入漏れ，回答しにくいとの指摘が多かったことから，平成 8 年 の質問票では表 3 に示す回答方法に変更した。また，「築年数」，「居 住年数」のカテゴリー構成も平成 8 年では変更した。

新幹線振動に対する心理的な構えを防ぐために，調查票では新幹 線の調査という言葉を使わずに，「地域の環境に関するアンケート調 査」とした。また，騷音に関する質問が振動を評価する上でのバイ アスとして作用することを防ぐために，振動，騒音の順で質問を配 置した。さらに，振動の直後に騒音に関する質問を配置すると，䮎 音に対する反忘にバイアスが作用する恐れがあるので，両項目の間 にダミーの質問としてゴミ問題に関する買問を設けた。調查実施機 関は横浜国立大学工学部建築環境工学研究室とした。

\section{3 振動・蜸音測定}

振動・騒音測定の概要を表 4 に示寸。調査地区に近い軌道中央力
らの距離が異なる $2 \sim 4$ 個の測定地点（例えば図 1 に示す $12.5 \mathrm{~m}, 2.5$ m, 50m, 80m の 4 地点) を 1 測線とし, 住宅の分布状況, 軌道の状況, 地形の変化等を考慮し，地区ごとに $2 \sim 6$ 本の測線を設けて測定を 行った。測定は，通過列車ごとの鉛直方向の振動レベルのピーク值， SLOW 特性の騒音レベルのピーク值をそれぞれ観測した。測定本数に ついては，勧告の中では連続する 20 本の列車を対象とすることが示

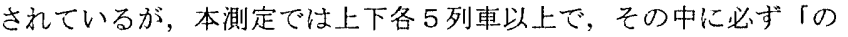
ぞみ」を含むこととした。

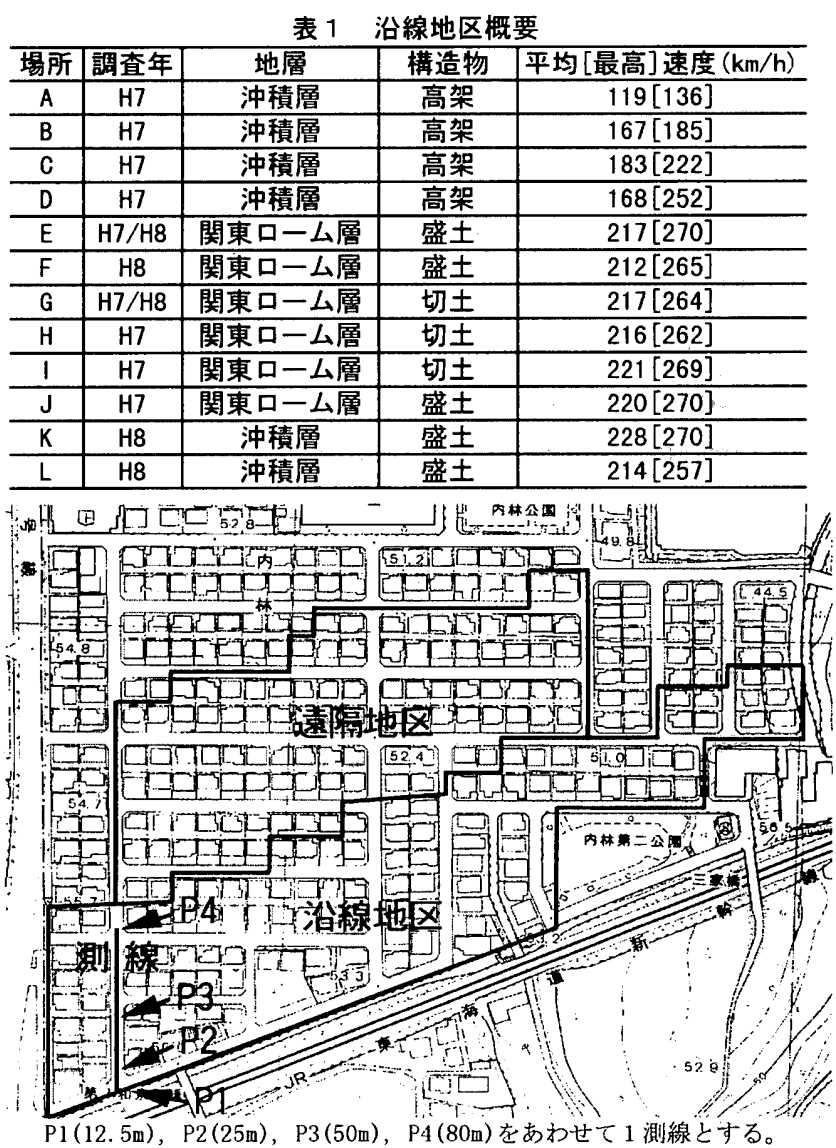

図 1 治線地区と遠隔地区

表 2 アンケート調査の实施状況

\begin{tabular}{c|c|c|c|c}
\hline & 配布 & 締め切り & 有効回収数 & 有効回収率 \\
\hline 平成 7年 & 10 月11 13日 & 11 月30日 & 469 & $67 \%$ \\
\hline 平成 8年 & 9 月25 26日 & 10 月25日 & 393 & $71 \%$ \\
\hline
\end{tabular}

\section{3. アンケート調査の集計結果}

アンケート調査の回答者及び住宅構造の主な属性について, 回答 数の上位 2 項目を表 5 に示す。対照地区において鉄骨住宅，高年齢， 専業主婦の割合が高い傾向は見られるものの, 地区による顕著な差 は見られなかった。回答者の傾向としては，築 10 年以上，木造住宅， $40 \sim 60$ 歳代, 女性, 専業主婦の回答が多く, 居住年数及び在宅時間 も長い傾向が見られる。

生活環境（18 項目）の買問項目の「周辺の静けさ」と「家の中の 振動」を地区ごとに比較するために，それぞれの集計結果を図 2 に 示す。主源である新幹線から灕れると住民の不満感は減少する傾向 が見られ，特に振動に関する不満率（『どちらかといえば不満』，『不 満』の割合）は沿線地区で $85 \%$ ，遠隔地区で $47 \%$ ，対照地区で 10\%上なっており，沿線地区での不満率が際立って高くなっている。 
表 3 調査票の主な質問項目

\begin{tabular}{|c|c|}
\hline 驻環境 & 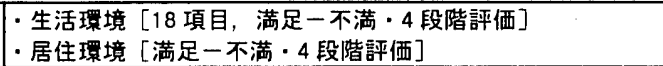 \\
\hline 振動 &  \\
\hline ゴミ問題 & ゴミ問題に対する知識・関心 \\
\hline 騒音 & 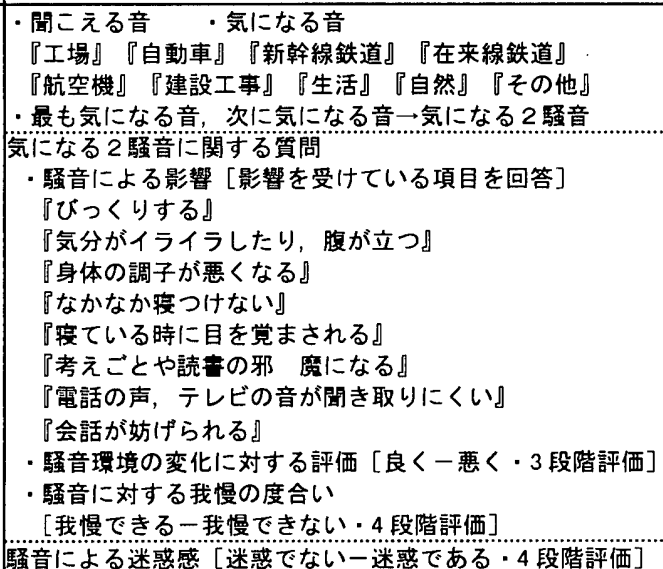 \\
\hline 告 & 住宅構造・築年数・居間，寝室の階数 \\
\hline & \\
\hline
\end{tabular}

表 4 振動 · 騒音測定の概要

\begin{tabular}{|c|c|}
\hline 測定日程 & 平成 7 年 11 月・平成 8 年 11 月 \\
\hline 測定項目 & $\begin{array}{l}\text { (振動) 鉛直方向・振動レベル・VL・ピーク值 } \\
\text { (騒音) A 特性・騒音レベル } \cdot \mathrm{SLOW} \cdot \text { ピーク值 }\end{array}$ \\
\hline 測定地点 & 地区毎の測定地点は $8 \sim 21$ 地点。 \\
\hline 測定本数 & 上下各 5 列車以上で，各 1 本「のぞみ」を測定 \\
\hline 測定機器 & $\begin{array}{l}\text { (振動) 振動レベル計 +レベルレコーダ } \\
\text { (騒音) 騒音計+レベルレコーダ }\end{array}$ \\
\hline 備考 & 測定時に列車通過速度及ひ車両形式等を観測 \\
\hline
\end{tabular}

表 5 回答者の属性及び住宅構造

\begin{tabular}{|c|c|c|c|}
\hline 性 & 線地区 (584) & 遠隔地区 (117) & 対照地区 (161) \\
\hline 別 & $\begin{array}{lllll}\text { 女性 } & : & 8 & 6 & \% \\
\text { 男性 } & : & 1 & 4 & 4\end{array}$ & \begin{tabular}{|lllll} 
女性 & $:$ & 8 & 7 & $\%$ \\
男性 & $:$ & 1 & 3 & 3
\end{tabular} & $\begin{array}{l}\text { 女性: } \\
\text { 男 }\end{array}$ \\
\hline 年齢 & $\begin{array}{l}0 \text { 歲代: } 31 \% \\
0 \text { 葴代: } 30 \%\end{array}$ & $\begin{array}{l}50 \text { 翽代: } 36 \% \\
40 \text { 歳代: } 33 \% \\
\end{array}$ & $\begin{array}{l}50 \text { 翽代: } 35 \\
60 \text { 歳代: } 26\end{array}$ \\
\hline 住 & $\begin{array}{l}0 \sim 19 \text { 年: } 33 \% \\
0 \text { 年以上: } 28 \%\end{array}$ & $\begin{array}{l}15 \sim 19 \text { 年: } 49 \% \\
10 \sim 14 \text { 年: } 17 \%\end{array}$ & $\begin{array}{l}15 \sim 19 \text { 年: } 3 \\
10 \sim 14 \text { 年 : } 3\end{array}$ \\
\hline 事 & $\begin{array}{l}\text { 尃業主婦: } 47 \% \\
\text { 有職者: } 37 \%\end{array}$ & \begin{tabular}{|l|} 
専業主媂: $51 \%$ \\
有 職 者: $41 \%$ \\
\end{tabular} & $\begin{array}{l}\text { 専業主㛿: } 65 \\
\text { 有 睵 者: } 23\end{array}$ \\
\hline 宅时 & $\begin{array}{l}1 \text { 日: } \\
16 \text { 時間： } 20 \% \\
\end{array}$ & \begin{tabular}{|cc:cccc}
1 & 日 & $:$ & 3 & 8 & $\%$ \\
半 & 日 & $:$ & 2 & 3 & 0
\end{tabular} & $\begin{array}{l}1 \text { 日: } 450 \\
16 \text { 時間: }: 210\end{array}$ \\
\hline ET侢迫 & 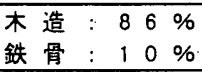 & 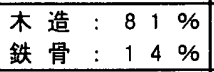 & $\begin{array}{l}\text { 木造 } \\
\text { 鉄 骨 }\end{array}$ \\
\hline & $\begin{array}{l}0 \sim 19 \text { 年: }: 35 \% \\
0 \text { 年以上: } 31 \%\end{array}$ & $\begin{array}{l}15 \sim 19 \text { 年: } 60 \% \\
20 \text { 年以上: } 15 \%\end{array}$ & $\begin{array}{l}15 \sim 19 \text { 年: }: 51 \% \\
20 \text { 年以上: } 22 \%\end{array}$ \\
\hline
\end{tabular}

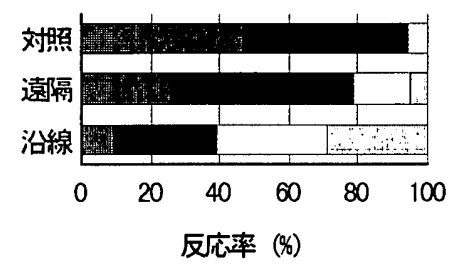

（a）周辺の静けさ

満足

どちらかといえば不満

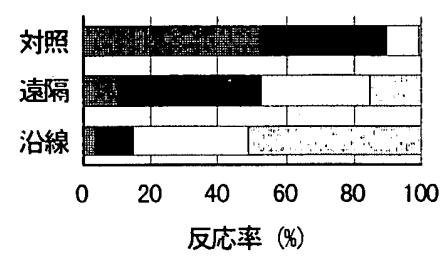

(b) 家の中の振動

范ちらかといえば満足

圆満

図2 アンケート調査の集計結果

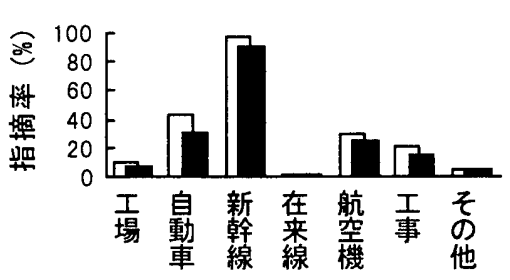

（a）沿線地区

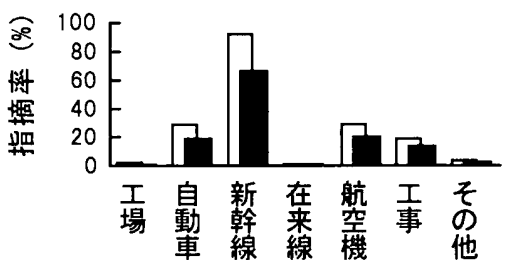

感じる振動

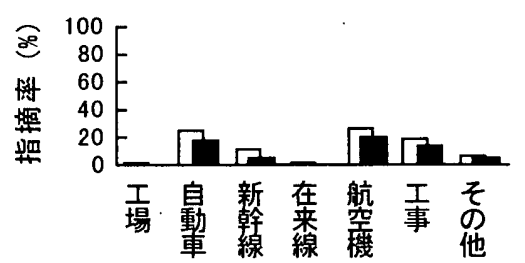

（c）対照地区

図 3 感じる振動・気になる振動

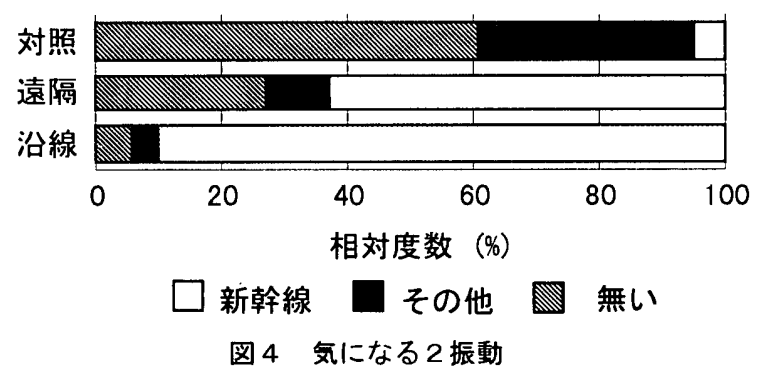

「感じる振動」，「気になる振動」の集計結果を図 3 に,「気にな る 2 振動」の集計結果を図 4 に示す。「気になる 2 振動」については, 新幹線を指摘した住民（新幹線），新幹線を指摘しなかった住民（そ の他)，何も指摘しなかった住民（無い）にま上めている。図 3から
新幹線以外の振動源に対する指摘率の差は地区間ではほとんど見ら れないが，新幹線に対する指摘率の差は認められ，指摘率の最も高 い沿線地区では 98\%の住民が新幹線振動を感じ，91\%が気にしてい る。図 4 からも, 沿線地区での新幹線振動に対する指摘率が非常に 高い $(90 \%) こ と か ゙$ 示されているので，振動が住民の日常生活に大き く影響を及ぼす要因となっていることが分かる。また，新幹線から $100 \mathrm{~m}$ 以上離れた遠隔地区・対照地区では, 図 3 や図 4 から新幹線 に対する指摘率が低くなっている。特に対照地区では, 新幹線振動 を感じている住民が少なく，新幹線以外の自動車や航空機を気にし ている回答者が多かったことから，振動は住民の生活に影響を及ぼ す要因ではないことが推測される。

以上のことから，日常生活に及ぼす新幹線振動の影響が最も顕著 
に見られる沿線地区（サンプル数は 584）を本報での分析対象とし た。なお，4.以降で用いる振動及び騒音は，新幹線に倸る振動及び 騷音を意味することとする。

\section{4. 振動及び騒音の懪露量の推定方法}

振動及び騒音に関する意識を分析する上で，住民が等露されてい る振動及び騒音の大きさを把握することが重要であるので，本研究 では以下の方法で曝露量を推定した。まず振動については，観測し た個々の列車の振動レベルから表 6 に示寸 6 種の評価值を算出し, 測線ごとに各々の対数距離减衰直線を作成した。各家尿に適用され る減衰直線を読み取ることによって各家屋におけるそれぞれの評価 値を推定し，その中で住民の振動による被害感（以下，「振動被害 感」という。）との対忘が最も良いものを振動に関する曝露量とした。 本研究で用いる「振動被害感」は，「気になる 2 振動」として新幹線 を指摘しなかった住民，何も指摘しなかった住民については『気に ならない』とし，新幹線を指摘した住民については「振動に対する 我慢の度合い」(『我慢できる』，『どちらかといえば我慢できる』，

『どちらかといえば我慢できない』，『我慢できない』）の対応する力 テゴリーを当てはめ，5段階評価（1.『気にならない』〜 5.『我慢 できない』)とした。今後『気にならない』とした住民は，日常，被 害感を全く抱いていないものとする。推定した 6 種の振動レベルの 評価值と「振動被害感」とのSpearman の相関係数を表 6 に示す。全 体的に相関係数が低いものの，相関が最も高い評価值は「300 系車 両の最大值」であることから，300 系車両の振動レベル最大值（以 下，「振動曝露量」という。）を振動の曝露量とした。騒音について も振動々同様な方法で検即を行った結果，300 系車両の騒音レベル 最大值（以下，「騒音曝露量」という。）を騒音の曝露量とした。そ れぞれの曝露量の度数分布を図 5 に示す。なお，振動及び騒音の曝 露量の平均值はそれぞれ $60 \mathrm{~dB}, 66 \mathrm{~dB}$ であった。

表 6 各評価值と新幹線振動評価の相関

\begin{tabular}{c|c}
\hline 振動レベルの評価値 & 相関係数 \\
\hline 全データの最大値 & 0.22 \\
\hline 全データのパワー平均 & 0.18 \\
\hline 上位半数のパワー平均 & 0.19 \\
\hline 上位半数の算術平均 & 0.18 \\
\hline 300 系車両の最大値 & 0.25 \\
\hline 0/100系車両の最大值 & 0.17 \\
\hline
\end{tabular}
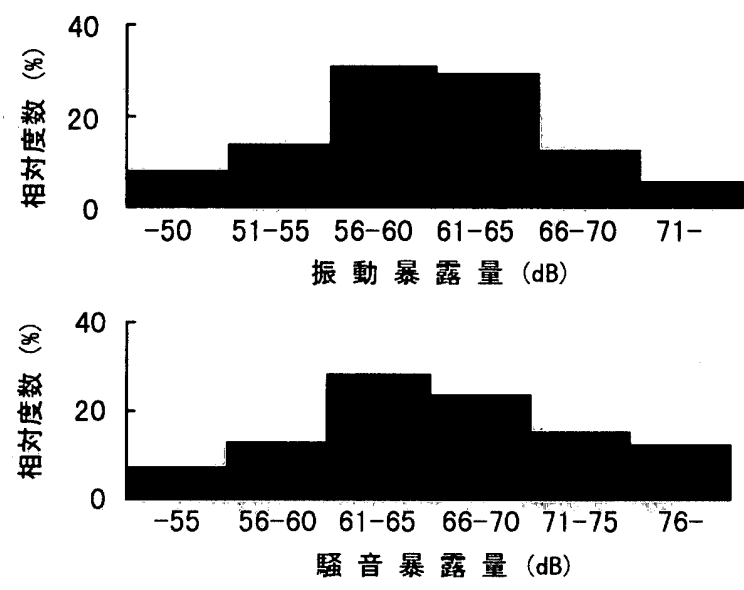

图 5 振動・騒音曝露量の分布

\section{5. 振動に対する住民反応}

\section{1 振動による影譩}

表 3 に示寸「振動による影響」の8 項目について,「振動被害 感」と同様な方法で新幹線による影響を整理し，住民が振動によっ て受けている影響を具体的に検討した。それぞれの項目について， 振動による影響を受けている住民の回答（平成 7 年の回答では『頻 繁にある』〜『時々ある』）を『影響ある』，影響を受けていない住 民の回答（平成 7 年では『ほとんよ゙ない』〜『全くない』）及び被害 感を抱いていない住民の回答を『影響ない』にまとめた。図 6 に 『影響ある』と回答した住民の割合（反忘率）を示す。「ガタつき」， 「ものゆれ」,「覚醒」の反応率が高く,「体調不調」や「入眠妨害」 の反忘率は低い。「ガタつき」は耳通して認知されていることから 振動による聴賞的な影響，「ものゆれ」は目を通して認知されている ことから振動による視覚的な影響であると考えられるので，図 6 は 聴覚的・視覚的影響を受けている住民が多いことを示している。

続いて反応率が高かった 5 項目について， $5 \mathrm{~dB}$ 単位でカテゴリ 一化した振動曝露量との関係を図 7 に示す。「ガタつき」の反応率は 全てのレベルにおいて最も高く，特に 50dB 以下でも反忘率が $65 \%$ と他の影響項目に比べ突出していることから，多くの住民は振動に よる聴覚的な影響を感知することで振動の存在を認知していると推 察される。「イライラ」，「覚醒」及び「ものゆれ」については，振動 の増大とともに反応率は直線的に増加する傾向が見られる。同様に， 住民が騒音によって受けている影響を検討した結果，「聴取妨害」， 「会話妨害」といった騒音固有の影響に対する反応が多かった。

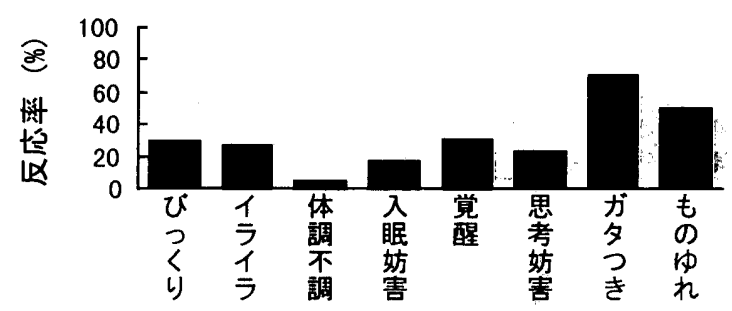

図6振動による影響項目の反応率

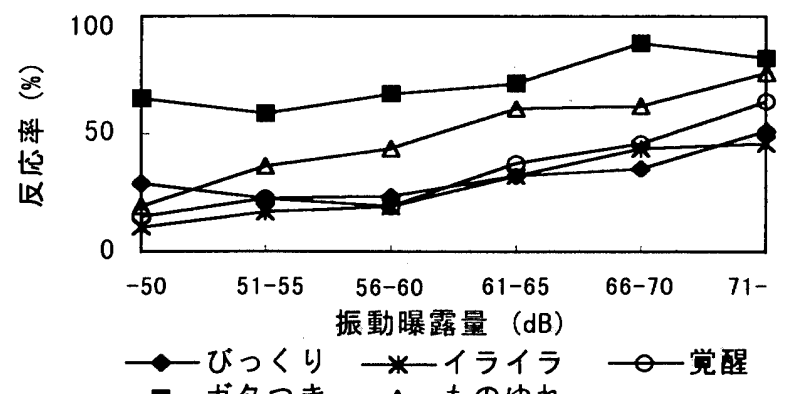

データ数:-50(42), 51--55(79), 56-60(183), 61-65(171), 66-70(76), -71(33) 図 7 振動曝露量と振動による影頯項目の関係

\section{2 「のぞみ」による振動環境の変化}

「のぞみ」の運行にともなう振動環境の変化を沿線住民がどのよ うに評価しているのかを検即した。本報では，前章で推定した振動 レベルの評価值「300 系車両の最大值」と「0/100 系車両の最大值」 の差（以下，「振動増幅量」という。）を振動の物理的変化䀶として 用いた。振動環境の変化に対守る住民評価（以下，「振動環境变化」 という。）については，「振動被害感」上同様な力法で整理し，『良 く』，『不変』，『悪く』及び『無回答』(被害感を抱いていない住民及 
び「のぞみ」運行後に住み始めた住民の回答）の4段階評価にまと めた。振動の物理的変化量と「振動環境変化」の関倸を図 8 に示寸。 振動増幅量が $2 \mathrm{~dB}$ 以上，すなわち 300 系車両の振動が $0 / 100$ 系車両 の振動よりも大きい場合には『悪く』の回答が多く，「のぞみ」の運 行により住民が振動環境の悪化を訴えていることが分かる。一方， 振動增幅量が-2dB 以下，寸なわち 300 系車両の振動が $0 / 100$ 系車耐 よりも小さい場合には，『不変』と回答している住民が多いものの，

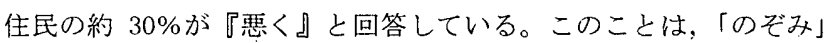
から発生する振動が小さく振動環境が改善されているにもかかわら ず，大幅なスピードアップによる振動增大という負のイメージ，住 環境に対するニーズの高まり等によって，振動環境の悪化を訴える 住民が少なからず存在することを示している。なお，『無回答』を除 外したクロス集計表に対して ${ }^{2}{ }^{2}$ の独立検定を行った結果, 振動增 幅量と「振動環境変化」に関連が見られた（有意水準 $5 \%$ ）ので, 『悪く』の增加傾向は有意であると考えられる。

\section{3 振動による被害感}

振動による沿線住民の被害感がどの程度であるのかを把握するた めに, 図 9 に振動の曝露量と被害感の反忘関係を示す。ここでは, 被害感の強反忘を『どちらかといえば我慢できない』及び『我慢で きない』として検討を行った。図 9 から『どちらかといえば我慢で きる』と回答している住民が最も多いが，振動の増大とともに被害 感は大きくなる傾向が見られ, 特に曝露量が $71 \mathrm{~dB}$ 以上の場合には住 民の約半数が被害感を強く訴えていることが分かる。また，新幹線 鉄道騒音に係る環境基準の場合には，反応率 $30 \%$ となるレベルを基 準值の基礎 ${ }^{15)}$ としていたことを参考にして，図 9 から強反応率が $30 \%$ 超える䝿露量を読み取ると，『66-70dB』になることが分かる。

振動による被害感の主要因を把握するために, 「振動被害感」を 外的基準, 振動による具体的影響（8項目）及び「振動環境変化」 を説明変数として数量化 II 類の分析を行った。「振動環境変化」の説 明変数は，『悪化』(『悪く』) と『良化』(『不変』, 『良く』, 『無回 答』）の 2 カテゴリーにまとめた。ここで，説明変数間の相関がやや 高いことから全変数での分析には多重共線性の問題が残るものの, 被害感のモデルを構筑する上で各要因の影響度を数量的に把握する ことは重要であると考えられる。分析結果を図 10 に示す。 偏相関係数が大きい要因は「ガタつき」(0.34),「振動環境変化」 (0.29), 「イライラ」(0.24), 「ものゆれ」(0.12) であり,「体調不 調」, 「入眠妨害」,「覚醒」の偏相関係数は小さい。レンジの大きさ についても同様な傾向が見られるので，多重共線性の影響は小さい と考えられる。以上のことから,「ガタつき」,「振動環境変化」,「イ ライラ」及び「ものゆれ」が被害感と強く関連していると考えられ る。一方, 「入眠妨害」や反応率の高かった「覚醒」に代表される睡 眠影響と被害感との関連はほとんど見られない。このことは, 深夜 の時間帯 (午前 0 時〜午前 6 時) には新幹線が運行されていないこ とに起因していると推測される。続いて被害感との関連が強い項目 について，それぞれのカテジリースコアの絶対值を比較してみる。 『影響ない』のスコアが最も大きいアイテムは「ガタつき」(0.64) である。『影響ある』のスコアが大きいアイテムは「イライラ」 (0.55)，「振動環境変化」(0.41)で，「ガタつき」(0.27) は前述の2 要因と比べる上さい。これらの結果から，振動に上る聴覚的影響 を感知していない住民被害感をほとんよ゙抱かないが，イライラ感
や振動環境の悪化感が住民の被害感を増大させていることが分かる。 すなわち，振動による被害感を低減するためには，これらの心理的 な影響を解消することが重要であると考えられる。
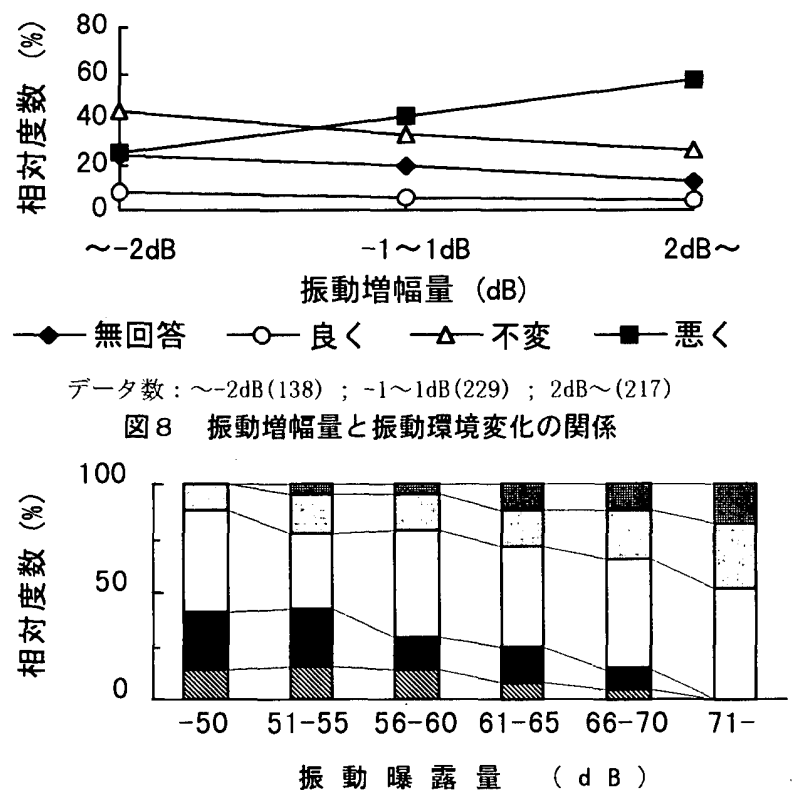

我慢できない

四どちらかといえば我慢できない

口どちらかといえば我慢できるロ我慢できる 匍気にならない

図 9 振動曝露量と振動被害感の関係

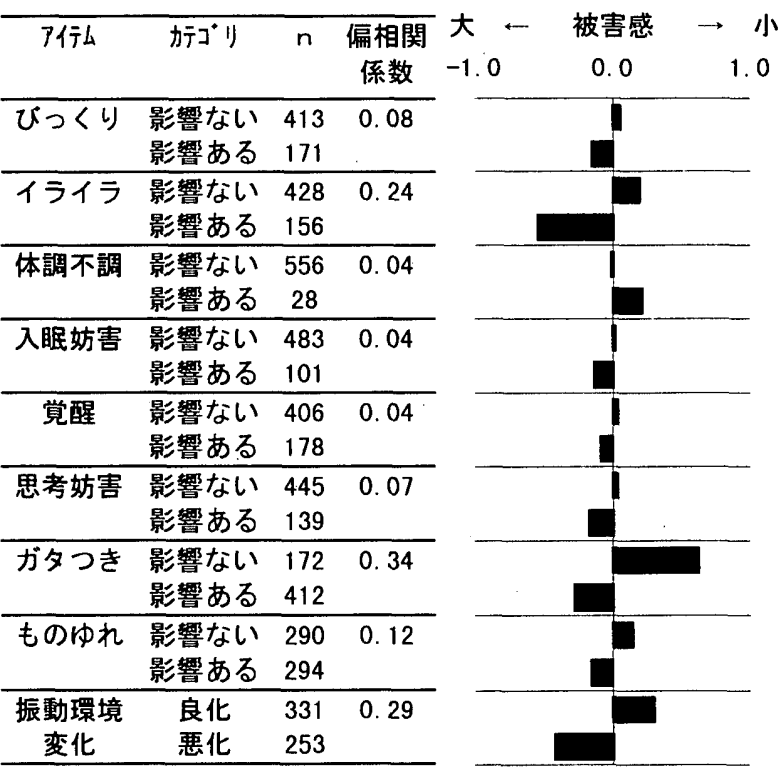

图 10 数量化 II 類の分析結果

\section{6. パス解析による分析 \\ 6. 1 パス解析}

曝露されている振動の大きさが住民の振動による被害感にどのよ うに影響しているのかを考えてみると，住民が体感する振動の大き さは被害感への直接的な影響要因であるとともに，戸等のがたつき や建具等の摇れ等を引き起こすことによって，間接的な影暃も及ぼ 寸要因であると想定できる。すなわち，曝露されている振動の大き さ，個人の属性，振動による影響等の様々な要因が重層的な関倸を 
構成して，振動による被害感は形成されていると考えることができ る。そこで, 説明変数から目的変数への直接的な影響（直接効果） 上間接的な影響（間接効果）を推定できるパス解析 ${ }^{16 \sim 18)}$ の手法を 用いて，各要因の影響度及び影響過程を明らかにする。

\section{2 パスモデルの設定}

既往の研究から得られている知見及び前章までに行った分析結果 を基にして，振動による被害感の因果モデル (パスモデル) を作成 した。図11に作成したパスモデルを示す。目的変数は「振動被害 感」（X12）で，説明変数は11 個の変数（X1〜X11）とした。

本モデルでは，曝露されている騒音及び振動の大きさ（X1：騒音 曝露量, $\mathrm{X} 2$ : 振動曝露量) 及び個人属性 (X3:築年数, X4:性別, $\mathrm{X} 5$ :年齢，X6:在宅時間) が，目的変数へ直接影響を及ぼすように， また騒音による影響（X7：聴取妨害)，振動による影響等 (X8：イラ イラ, X9：ガタつき, X10：ものゆれ，X11：振動環境変化）を介し て間接的に目的变数へ影響を及ぼすようにモデルを設定した。X1〜 $\mathrm{X} 6$ は外生変数, X7〜X11 は内生変数である。識別性の問題 ${ }^{16)}$ を避け るために，下位レベルにある変数はそれより上位レベルにある全変 数に対してパスを設定した。例えば，「振動曝露量」（X2）は，それ より上位レベルにある変数（X7〜X12）に対してパスを通した。なお， 多重共線性の影響をできるだけ避けるために，外生変数は互いにな るべく相関の低い変数を選んだ。

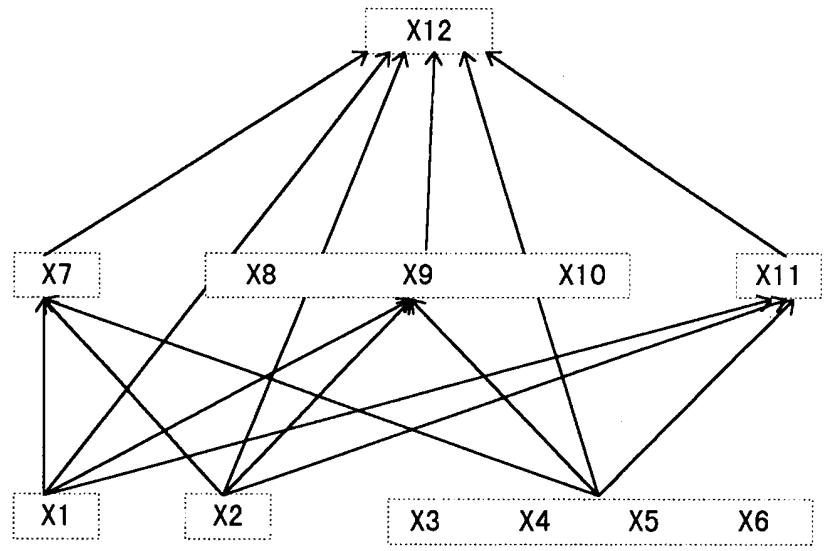

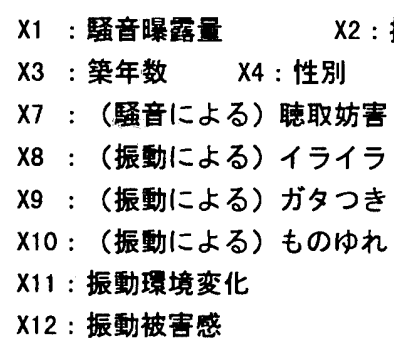

图 11 振動被害感のパスモデル

\section{3 変数の尺度構成}

原則としてパス解析における変数は，間隔尺度又は比例尺度の連 続量でなければならない。アンケート調査結果の大部分は順位尺度 又は名義尺度であるので，パス解析を適用できるように尺度を再構 成する必要がある。分析で用いる説明変数の尺度構成を表 7 に示す。 「築年数」,「年齢」,「在宅時間」については, アンケート調查で得 られた結果は順序尺度であるが，カテゴリ一の中間值あるいは上限 值等を代表值とし近似的に間隔尺度とみなした。目的変数である 「振動被害感」も順位尺度であるので，そのまま分析に用いるのは
議論のあるところであるが，H. B. Asher ${ }^{16)}$ はこの問題についていく つかの例を挙げながら肯定的な意見を示しており，本報でも近似的 に間隔尺度として扱うこととした。

表 7 説明变数の尺度構成

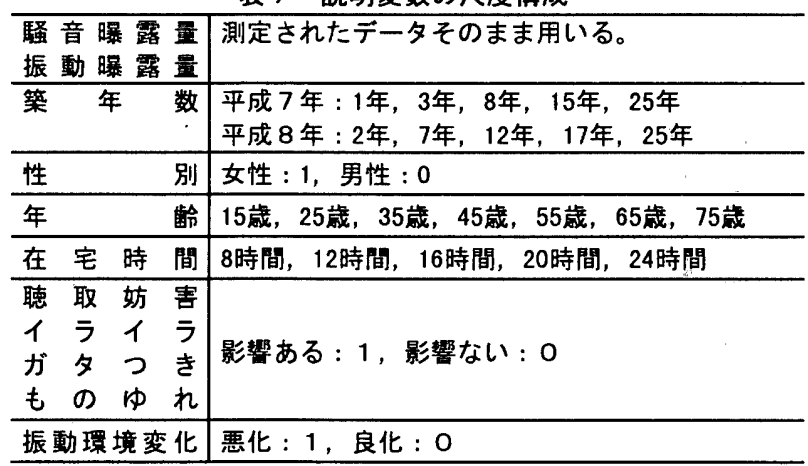

\section{4 分析結果}

要因の効果を表す影響指標（パス係数）は，パスモデルから決定 される構造方程式（重回帰方程式）を解くことによって得られる標 準偏回帰倸数である。各要因の効果の大きさについては，直接効果 はパス係数そのもの，間接効果はパスで結ばれる変数間のパス係数 の積，総合効果は直接効果上間接効果の和でそれぞれ推定される。 各要因の効果の大きさを図12に示すとともに，「振動被害感」(X12) へのパス係数が有意なもの（t 検定で $5 \%$ 水準）だけを取り出した 修正モデルを図13に示す。本分析における寄与率は0.48であった。

直接効果が大きい変数は「イライラ」(0.31),「ガタつき」 (0.26),「振動環境変化」(0.26) で,「騒音曝露量」及び「振動曝 露量」の直接効果は有意でない。間接効果が大きい変数は「振動曝 露量」(0.25) で，全ての内生変数 $(X 7 \sim X 11)$ を介して有意な効果を 及ぼしており，特に「イライラ」(X8)，「ガタつき」(X9)及び「振動 環境変化」(X11)を介しての効果が大きかった。総合効果が大きい変 数は「イライラ」(0.31),「ガタつき」(0.26),「振動環境変化」 （0.26）で，「振動レベル」（0.24）は4番目である。また，「騒音曝 露量」及び個人属性（「築年数」，「性別」，「年齢」及び「在宅時 間」）の総合効果は小さいが，図13から4変数とも被害感に対する直 接又は間接効果仙有意であることが分かる。以上のことから被害感 の評価構造は，作成したパスモデルで概ね表現されていると考える ことができる。各要因の効果の大きさ及び影響過程から判断すると, 被害感を構成する主要因は，振動によるイライラ感，聴覚的影響， 環境変化及び曝露されている振動の大きさである。特に振動の曝露 量は, 被害感への直接的な要因であるというよりも，振動による影 響等を介した間接的な要因である。このことは，聴覚的・視覚的影 響の効果が有意であることを踏まえると，住民が振動を実際に体感 していない場合でも，振動によって発生する建具のがたつき等によ って被害感が生じる可能性を示唆している。「騒音曝露量」(X1) に ついては，直接効果は有意でないが，「聴取妨害」（X7）を介しての 間接効果は有意であるので, 騒音も振動による被害感を構成する要 因である(9) ことを示している。

有意な効果を及ぼしている個人属性について多少の考察を加える。 まず「築年数」（X3）を見てみる。一般的に古い家屋では振動の増幅 が大きくなるために被害感が強くなり, 直接効果は正になると想定 されたが, 得られたパス係数は負で, 古い家屋の住民の被害感は小 
さいことを意味している。このことは築年数と居住年数の間に高い 相関が見られることから，その地域に長い間居住している住民は振 動に対する慣れやあきらめ等によって被害感が薄まってしまったと 推定できる。「年龄」（X5）については，直接効果，「聴取妨害」及び 「ガタつき」を介しての間接効果が有意である。若年・中年層と比 べると高齢の住民は騒音及び振動による影響を感じにくくなるので, 間接効果は被害感を低減させるように㗢くが, 被害感そのものは厳 しくなる傾向にあることを示している。「在宅時間」（X6）について は，「聴取妨害」及び「振動環境変化」を介しての間接効果が有意で ある。在宅時間の長い住民は騒音及び振動による諸影響をより多く 受けるので間接効果による被害感が増大寸ると考えられる。

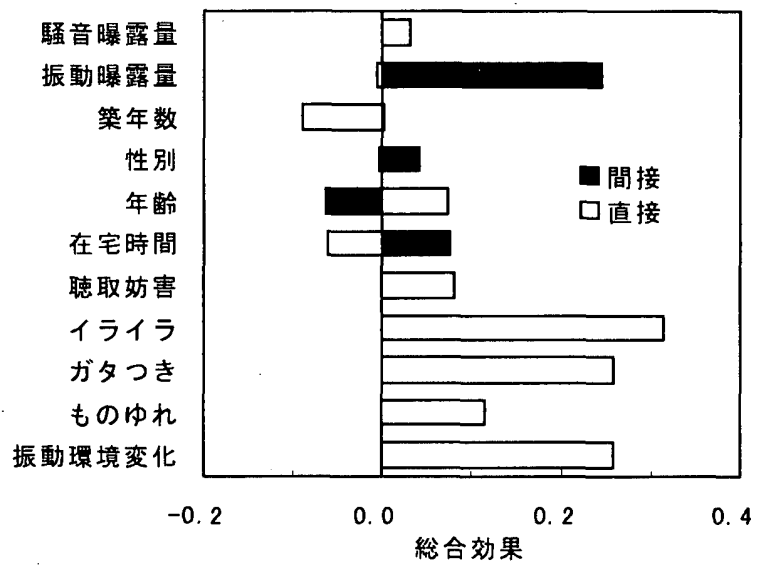

図 12 効果の大きさ

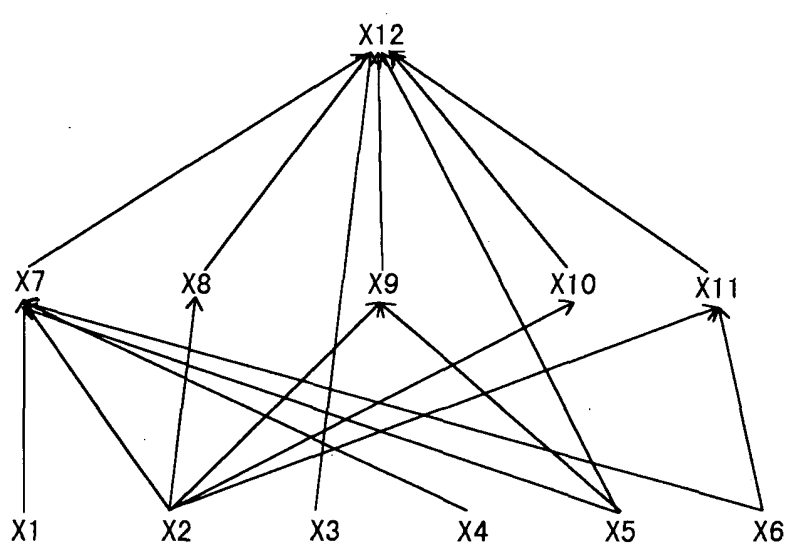

図 13 有意なパスによる修正モデル

\section{7. まとめ}

本論文では平成 7 年及び 8 年に行った東海道新幹線沿線の戸建て 住宅を対象としたアンケート調査から，住民の新幹線振動及び騒音 に対する意識を把握するとともに，新幹線振動による被害感の構成 要因を解明した。得られた結果を緾めると以下のとおりである。 1)軌道から $100 \mathrm{~m}$ 以内の沿線地区では，大部分の住民が新幹線振動 を感じている上に, 約 9 割の住民が振動を気にしていることから， 新幹線振動住民の日常生活に影響を及ぼしている。一方，軌道 から $200 \mathrm{~m}$ 以上離れた対照地区では，新幹線振動を気にしている 住民は少なく，日常生活への影響はほとんどない。

2) 新幹線振動による影響では「ガタつき」の反忘が最も多く，この 聴覚的な影響を感知することで新幹線振動を認知する住民が多い。 3「のぞみ」の運行によって新幹線に係る振動環境が琹化している
所では，多くの住民が振動環境の悪化を訴えている。一方，振動 環境が改善されている所でも振動環境の悪化を訴える住民が存在 しているが，これは，従来型よりも大幅なスピードアップをして いる「のぞみ」に対するマイナスイメージによるものと思われる。

4) 新幹線振動による住民の被害感と振動による聴覚的影響, イライ ラ感及び振動環境の悪化感との関連は強く，特にイライラ感や環 境悪化感は被害感を増大させる要因である。

5) パス解析の結果, 新幹線振動による被害感を構成する主要因は, 振動によるイライラ感，聴覚的影響，環境変化及び振動の曝露量 である。イライラ感，聴賞的影響，環境変化の影響は直接的要因 で，振動の曝露量は間接的要因である。

6) 新幹線騒音も新幹線振動による被害感を構成する要因の1つであ る。

\section{[謝辞]}

共同研究者の横浜国立大学修論生林真行 (現旭硝子)，卒論生金子誠 (現三井ホーム) の両氏には，研究の実施，デー夕解析にあたって多 大なる協力を頂きました。ここに記して深想なる謝辞を申し上代ます。

[参考文献]

1) 神奈川県大気保全課 : 新幹線鉄道騒音振動調査結果報告書, 1994.3

2）横島潤紀他 5 名 : 新幹線鉄道から発生する地盤振動について一新型 車両 300 系の場合-, 日本騒音制御工学会技術発表会講演論文集, pp. $81-84,1993.9$

3）曽根敏夫，香野俊一，二村忠元，亀山俊一，熊谷正純 : 沿線住民に 及ぼす新幹線鉄道騒音の影響，音響学会誌，Vol. 29，No. 4，pp. 214224, 1973.4

4）田村明弘 : 在来線及び新幹線沿線住民の騒音に対する社会反忘，音 響学会馶音振動研究会資料, N-89-37, 1989.7

5）町田祐治 : 新幹線鉄道騒音に関する意識調查について，音響学会䮎 音振動研究会資料, $N-89-36,1989.7$

6）川端徽朗 : 東北新幹線騒音が学童の生活環境に及ぼす影響，日本公 衛誌, Vol. 38, No. 1, pp. 52-63, 1991. 1

7）川端徽朗 : 新幹線騒音に対する学童のうるささの訴えの程度に関連 方る要因，日本公衛誌，Vol.41，No. 12，pp. 1131-1141，1994. 12

8）村松常司他 7名：新幹線騒音，振動等の健康に及ぼす影響に関寸る 研究（第 1 報)，日本公衛誌，Vol. 23，No. 8, pp. 471-481, 1976.8

9）住友聰一, 辻本三郎丸: 新幹線鉄道沿線の騒音・振動について, 兵 庫県公害研究所報告第 20 号, pp. 95-105，1988

10）平尾善裕，横田明則：変動振動の全身曝露に対する評価実験，騒音 振動研究会資料，N-94-53，1994. 11

11）石川孝重, 野田千津子 : 広振動数範囲老対象とした水平振動感覚の 評価に関する検討，日本建築学会計画采論文集，№. 506，pp. 9-16, 1998. 4

12）横崮潤紀，林真行，田村明弘：新幹線沿線住民の振動に対する評佂 を構成する要因について (その $1 \cdot 2)$, 日本建築学会学術講演梗 概集 (近畿)，pp. 297-300，1996.9

13）横島潤紀，大塚定男，田村明弘：新幹線沿線住民の振動に対する評 価を構成する要因について（その3)，日本建築学会学術講演梗概 集 (関東)，pp. 253-254，1997.9

14）横島潤紀，梅田成道，大塚定男，田村明弘 : 新幹線及び在来線沿線 住民の振動に対する社会的反応 $($ Zの $1 \cdot 2)$ ，日本建築学会学術 講演梗概集 (九州), pp. 317-320，1998.9

15）環境庁大気保全局編：騒音規制法の解説（三訂），新日本法規 株式会社，1994.6

16）H. B. Asher（広瀬弘忠訳）：因果分析法，朝倉書店，1980

17）佐藤哲身：道路交通騒音のうるささに及ぼす振動影響のパス解析， 日本建築学会計画系論文集，No. 439，pp. 13-18，1992.9

18）山下敏夫, 矢野隆, 泉清人, 黑澤和隆 : 北海道亡九州に扔ける道路 交通騒音に対する社会反忘の多変量解析 道路交通騒音に対する社 会反応の地域比較研究 I, 日本建築学会計画系論文集, No. 451 , pp. 9-18, 1993.9

19）西宮元：騒音・振動に関する社会反忘上その特徵について，日本音 響学会誌, Vol. 32, No. 3, pp. 147-155, 1976.3

（1999年 2 月10日原稿受理，1999年 8 月 2 日採用決定） 